\title{
Antimicrobial and toxicity tests of flavonoid total Dendrophthoe pentandra (L) miq from false ashoke tree (Polyalthia longifolia)
}

\author{
Aliyah Fahmi ${ }^{{ }^{*}}$, Rumondang Bulan Nasution ${ }^{1}$, Hamonangan Nainggolan ${ }^{\mathbf{1}}$ \\ ${ }^{1}$ Department of Chemistry, Post Graduated, Faculty of Mathematics and Natural Science, Universitas Sumatera Utara, Medan-Indonesia
}

\section{Abstract:}

Research on antimicrobial and toxicity tests of flavonoid total Dendrophthoe pentandra (L) Miq from false ashoke tree (Polyalthia longifolia) have been done. This study aims to determine the activity of toxicity of total flavonoid of Dendrophthoe pentandra (L) Miq as mistletoe of false ashoke tree ( $P$. longifolia) based on Brine Shrimp Lethality Test (BSLT) method using Artemia salina Leach shrimp larvae obtained Lethal Concentration $\left(\mathrm{LC}_{50}\right)$ of $30.06 \mathrm{mg} /$ $\mathrm{L}$ which means strong toxic activity. Antimicrobial test of flavonoid total has used the diffusion method in order to obtain the inhibit zone diameter on Streptococcus mutans at the total flavonoids concentration of 3\%, 6\% and 9\% were 6; 9 and $17.25 \mathrm{~mm}$, in Escherichia coli is 3.55; 4.25 and $9.15 \mathrm{~mm}$ and at Candida albicans is 8.30; 4 and 5.30 $\mathrm{mm}$ where $S$. mutans and $E$. coli are greater but $C$. albicans less affect but still have good inhibitory activity so effective to be developed as antimicrobial agents.

Keywords:

false ashoke leaves, antimicrobial, toxicity, diffusion and BSLT

\section{Introduction}

As a biodiversity mega country, Indonesia has a wealth of biodiversity. A number of studies were conducted to examine the potential of plants in Indonesia as raw materials of the drug. There are approximately 7000 species of plants including medicinal plants of \pm 28.000 species of plants that can be found in Indonesia. Medicinal plants are groups of plants that can be used as medicine or raw materials of medicine. Utilization of medicinal plants is usually in the form of simplicia from plant parts such as roots, stems, leaves, and fruit or seeds (Fatmawati, 2008).

Parasitic plants are also known as medicinal plants called with mistletoe or in Indonesia called Benalu. The mistletoe from coffee tree is usually used to treat measles. The mistletoe from lime tree is used as a medicinal herb for tonsil diseases, while mistletoe of tea and mango reported can be used as a cure for cancer (Purnomo, 2000). Clinical effects on mistletoes are thought to be due to the presence of bioactive compounds contained inside of amino acids, carbohydrates, flavonoids, alkaloids, and saponins that can neutralize the effects of toxic substances thereby reducing cell damage (Pitojo, 1996).

The trees are plenty to see as plants for noise pollution dampers and have benefits as medicinal plants for skin diseases, fever, hypertension and helmenthiasis (Rastogi et al., 1995). Several recent

\footnotetext{
* Corresponding author.

faradisty@yahoo.com

doi: https://doi.org/10.24114/jpkim.v10i1.9677
}

studies have shown that $P$. longifolia trees function as antidiabetic drugs (Lakshmi et al., 2011), anti-ulcer (Malairajan et al, 2008) and effective for Hela and MCF-7 cells (Manjula et al., 2010). Mistletoe on Polyalthia longifolia trees can be meet on their branchs. For the mistletoe of that trees, no one has tested it's activity as medicinal plants. Therefore, the authors wish to examine the toxicity and antimicrobial activity of the total flavonoids of mistletoe leaves of $P$. longifolia trees and their phytochemical screening.

As we know from the family, P. Longifolia is one family of Annonaceae which is family of soursop tree and nona tree which have been tested have antimicrobial activity and high toxicity because it has content of active compounds which is as phytopharmaca drug.

\section{Materials and Methods \\ Materials}

Mistletoe Leaves of $P$. longifolia tree, Methanol pa Merck, Brataco Technical Methanol, Technical N Hexana , Technical Ethyl Acetate, Mayer Reagent, Dragondorf Reagent, Wagner/ Bouchardat Reagent, Aquadest, DPPH p.a Sigma Aldrich, $\mathrm{FeCl}_{3}$ p.a Merck, DMSO p.a Merck, Artemia salina Cyst , Aquadest, Sea Salt Packaging, Mueller Hinton Agar, Nutrient Agar, Nutrient Broth, E. coli culture, S. mutans culture and Candida albicans culture.

\section{Sample Preparation}

Mistletoe leaves of $P$. longifolia that grow around the USU Library were collected purposively (not 
comparing with other regions) as samples. Mistletoe leaves cleaned and weighed further in the dry-aired. After drying, the sample was smoothed using a blender. Then as much as $200 \mathrm{~g}$ of sample was added to Erlenmeyer glass added with $1 \mathrm{~L}$ of methanol. Maserated for 24 hours at room temperature. The maserate was then added with methanol back to the sample of mistletoe leaves to the clear-colored solvent then collected the filtered maserate, evaporated with a Rotary Evaporator under vacuum until a viscous extract was obtained. The viscous extract was evaporated until the solvent evaporates completely and obtained a concentrated extract of sample. (Rl, 2000). Furthermore, the concentrated extract of mistletoe leaves was dissolved with ethyl acetate filtered then the filtrate was evaporated until the solvent completely evaporated so as to obtain the ethyl acetate extract of mistletoe leaves which was then reconstituted with methanol until completely dissolved and in partition with $\mathrm{n}$-hexane formed two layers, the bottom layer was taken and evaporated until the total flavonoid is obtained.

\section{Phytochemical Test Alkaloid Test}

A total of \pm 5 drops of filtrate of methanolic mistletoe leaves extract were each dropped on four test tubes. The first reaction tube was dropped by 2 drops of Mayer reagent (positive for forming a white or turbid precipitate), the second reaction tube was dropped 2 drops of Dragendorf reagent (positive for orange precipitate formation), the third reaction tube drops 2 drops of Wagner reagent (positive if it formed brown red precipitate) and the fourth test tube drops 2 drops of Bouchardat reagent (positive if formed a red precipitate). Observed changes that occur (Harborne, 1987).

\section{Phenolic Test}

A total of \pm 5 drops of filtrate of methanolic mistletoe leaves extract was dropped on a test tube then added each with 3 drops of $1 \% \mathrm{FeCl}_{3}$ solution (positive if blackish brown). Observed changes that occur (Harborne, 1987).

\section{Flavonoid Test}

A total of \pm 5 drops of filtrate of methanolic mistletoe leaves extract was dropped onto a test tube with \pm 3 drops of ethyl acetate plus 2 drops of $\mathrm{FeCl}_{3}$ $1 \%$ to form a green to brownish color (positive to green to brownish). Observed the color changes that occur (Harborne, 1987).

\section{Terpenoid and Steroid Test}

\section{Liebermann Bouchard Test}

A total of $\pm 20 \mathrm{~mL}$ of partial methanolic mistletoe leaves extract was fed into the beaker glass then evaporated until the solvent was exhausted then cooled and then dropped \pm 5 drops of anhydrous acetate and \pm 5 drops of concentrated sulfuric acid (positive terpenoid if brownish to violet and positive steroid form if color was formed green to blue). Observed changes that occur (Harborne, 1987).

\section{Thin Platform Test}

As much as $\pm 3 \mathrm{~mL}$ of methanolic mistletoe leaves extract spilled on a thin plate heated on a hotplate in \pm 2 drops of concentrated sulfuric acid (positive terpenoid if reddish) (Harborne, 1987).

\section{Saponin Test}

A total of \pm 5 drops of methanolic mistletoe leaves extract was inserted in a test tube then with $20 \mathrm{~mL}$ of aquadest. The cooled filtrate was then shaken strongly for 10's and stays for $10 \mathrm{~min}$ (positive if foam was formed). Observed changes that occur (Harborne, 1987).

\section{Toxicity Test by Brine Shrimp Lethality Test Method (BSLT)}

\section{Preparation of Shrimp Larvae}

The mother liquor of the container was insulated in two parts, filled with $38 \mathrm{~g}$ of sea salt dissolved in 1 $\mathrm{L}$ aquadest obtained by artificial seawater. A total of $20 \mathrm{mg}$ of Artemia salina eggs were inserted in a closed partition and one partition was left open, then lighted over an open section to draw Artemia salina shrimp to the light-affected part so that it was separated from its shell. The eggs of Artemia salina would hatch into larvae within 24-48 hours of hours and were used toxicity test from the total flavonoid of mistletoe leaves extract. Made standart solution with $100 \mathrm{mg}$ of flavonoid total of mistletoe leaves extract plus 3 drops DMSO, dissolved to $10 \mathrm{~mL}$ with artificial sea water obtained concentration of standart solution was $10.000 \mathrm{mg} \mathrm{/} \mathrm{L}$ then diluted to 3 concentration that is 10,100 and $1000 \mathrm{ppm}$. Concentration of $0 \mathrm{ppm}$ as negative and positive control with the addition of DMSO (McLaughlin et al., 1998).

\section{Toxicity Test}

A total of 10 larvae were inserted into each test tube that had filled $5 \mathrm{~mL}$ of concentrated extract solution of mistletoe leaves extract with concentration of 1000, 100 and $10 \mathrm{ppm}$ respectively. Three repetitions made. After 24 hours, observed the number of dead larvae for each concentration.

\section{Antimicrobial Test}

\section{Testing Antimicrobial Activity with Agar Diffusion}

Prepared $10 \mathrm{~mL}$ of $\mathrm{Mc}$ solution. Farland $\left(10^{8} \mathrm{CFU} /\right.$ $\mathrm{mL}$ ) was then taken Streptococcus mutans with sterile ose needle then put into $10 \mathrm{~mL}$ of aquadest in the test tube then in suspension, mixed with vortex until homogeneous and closed tube with cotton and seal wrap. Streptococcus mutans on a petri dish containing sterile MHA then perforated MHA on 
petri that has been applied with a uniform hole using Cop Borer then put $50 \mu \mathrm{L}$ of test sample with concentration $3 \%, 6 \%, 9 \%$ and DMSO as blank then sealed with seal wrap and incubated at temperature $35 \pm 2^{0} \mathrm{C}$ for 24 hours. Further, measured the diameter of the drag area around the hole by using the sliding term. Do the same thing on Escherichia coli and Candida albicans (Ditjen POM, 1995).

\section{Results}

\section{Sample Preparation}

Fresh mistletoe leaves as sample were cleaned and then dried were weighed as the initial weight of 1000 g. Then the sample was allowed to dry until the leaves could be kneaded in the room ( \pm 1 week) and weighed again as the final weight of $230 \mathrm{~g}$ or by $23 \%$. $200 \mathrm{~g}$ of leaf parasite powder was macerated with methanol solvent for 1 night and then filtrate and macerated until the filtrate of the sample was colorless or clear then the filtrate was evaporated with a rotary evaporator at $60^{\circ} \mathrm{C}$ and concentrated with a water bath obtained by methanol condensed extract of 24, $5 \mathrm{~g}$ or $12.25 \%$ and then dissolved with ethyl acetate and evaporated. Ethyl acetate extract was dissolved with methanol and fractionated with nhexane and the bottom layer was evaporated until dried as total flavonoid then weighed $4.98 \mathrm{~g}$ or by $2.49 \%$.

\section{Tests of Phytochemical}

Table 1

Phytochemical screening of metanolic leaf extract

\begin{tabular}{|c|c|c|}
\hline Groups & Reagents & Results \\
\hline \multirow[t]{4}{*}{ Alkalod } & Meyer & - \\
\hline & Buchardat & - \\
\hline & Dragendorf & - \\
\hline & Wagner & - \\
\hline \multirow[t]{2}{*}{ Fenolik } & $\begin{array}{l}\text { Flavonoid (Ekstrak Et.asetat } \\
\left.\mathrm{FeCl}_{3} 1 \%\right)\end{array}$ & ++++ \\
\hline & $\begin{array}{l}\text { Fenolik (Ekstrak Metanol } \mathrm{FeCl}_{3} \\
1 \% \text { ) }\end{array}$ & ++++ \\
\hline Saponin & Aquadest & - \\
\hline \multirow{2}{*}{$\begin{array}{l}\text { Terpenoid/ } \\
\text { Steroida }\end{array}$} & Lieberman Bouchard & +++ \\
\hline & $\begin{array}{l}\mathrm{CeSO}_{4} 1 \% \text { dalam } \mathrm{H}_{2} \mathrm{SO}_{4} \\
\text { dengan Plat TLC }\end{array}$ & +++ \\
\hline
\end{tabular}

Test toxicity activity with brine shrimph lethality test (BSLT)

Table 2

Observations with BSLT

\begin{tabular}{ccc}
\hline $\begin{array}{l}\text { Concentration } \\
(\mathrm{ppm})\end{array}$ & $\begin{array}{l}\text { Lived Larvae } \\
\text { Number }\end{array}$ & $\begin{array}{l}\text { Died Larvae } \\
\text { Number }\end{array}$ \\
\cline { 3 - 3 } 1000 & 10 & 24 hours \\
\hline 10 & 10 & 10 \\
100 & 10 & 10 \\
& 10 & 2 \\
10 & 1 \\
10 & 1
\end{tabular}

$\begin{array}{ccc}10 & 10 & 0 \\ & 10 & 1 \\ \text { Blank }+ & 10 & 1 \\ 3 \text { Blank }- & 10 & 0 \\ & 10 & 0 \\ & 10 & 0 \\ & 10 & 0\end{array}$

From Table 2 Observation with Brine Shrimph Lethality Test at concentration $1000 \mathrm{ppm}$ be seen total shrimp larvae mortality of total flavonoid from mistletoe leaves extract to the three test tubes containing shrimp larvae suffered total mortality while for the concentration of 100 and $10 \mathrm{ppm}$ be seen mortality rate of low shrimp larvae.

Table 3

Observation of toxicity activity test with BSLT during 24 hours

\begin{tabular}{|c|c|c|c|c|c|c|c|c|}
\hline $\begin{array}{l}\text { Concent } \\
\text { ration } \\
\text { (ppm) }\end{array}$ & $\begin{array}{l}\text { Lived } \\
\text { Larvae } \\
\text { Number }\end{array}$ & $\begin{array}{c}\text { Died } \\
\text { Larvae } \\
\text { Number }\end{array}$ & A & B & C & $\mathrm{B}+\mathrm{C}=\mathrm{D}$ & B/D & E \\
\hline \multirow[t]{3}{*}{1000} & 10 & 10 & & & & & & \\
\hline & 10 & 10 & 10 & 10 & 0 & 10 & 1 & 100 \\
\hline & 10 & 10 & & & & & & \\
\hline \multirow[t]{3}{*}{100} & 10 & 2 & & & & & & \\
\hline & 10 & 1 & 1,3 & 11,3 & 8,7 & 20 & 0,57 & 57 \\
\hline & 10 & 1 & & & & & & \\
\hline \multirow[t]{3}{*}{10} & 10 & 0 & & & & & & \\
\hline & 10 & 1 & 0,6 & 12 & 18,1 & 30,1 & 0.40 & 40 \\
\hline & 10 & 1 & & & & & & \\
\hline
\end{tabular}

Note:

A: Average of Dead Larvae, B: Accumulation of Dead Larvae, C: Life Lifecycle Accumulation, D: Total Mortality and E: Percent of Mortality

From Table 3 Observation of Toxicity Activity Test with Brine Shrimph Lethality Test for 24 hours\% mortality obtained at total flavonoid concentration $10 \mathrm{ppm}$ is $40 \%, 100 \mathrm{ppm}$ was $57 \%$ and $1000 \mathrm{ppm}$ was $100 \%$. If Percent Mortality was $\mathrm{Y}$ axis and antilog as $\mathrm{X}$ axis then obtained graph as follows.

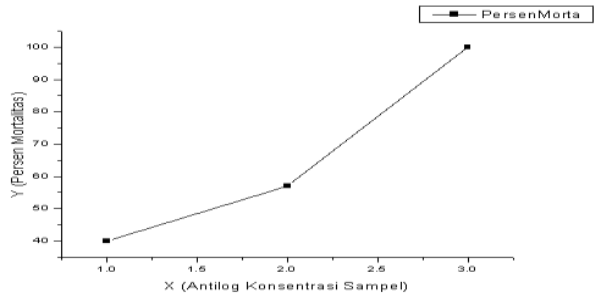

Fig 1. Graph of toxicity activity of BSLT where $X$ as antilog of total flavonoid of mistletoe leaves and $Y$ as \% mortality.

Test of antimicrobial activities of flavonoid total from mistletoe leaves

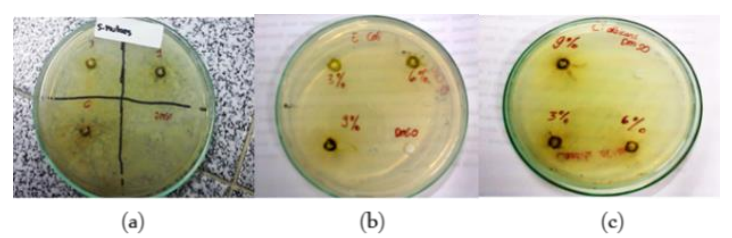

Fig 2. Test of Antimicrobial Activity (a) S. mutans (b) E. coli and (c) Candida albicans. 
From Fig 2 be seen inhibition zone of Negative Bacteria of S.mutans, E. coli and $C$. albicans to concentration of $3 \%, 6 \%$ and $9 \%$ of flavonoid total from mistletoe leaves extract and DMSO as blank.

\section{Table 4.}

Results of measurement of inhibitant zone flow test of antimicrobial activity flavonoids total from mistletoe leaves extract

\begin{tabular}{cccc}
\hline Konsentrasi & \multicolumn{3}{c}{ Diameter Zona Hambat $(\mathrm{mm})$} \\
$(\%)$ & S. mutans & E. coli & C. Albicans \\
\hline 3 & 6 & 3.55 & 8.30 \\
6 & 9 & 4.25 & 4 \\
9 & 17.25 & 9.15 & 5.30 \\
Blanko & 0 & 0 & 0 \\
\hline
\end{tabular}

From the table above we saw the graph below:

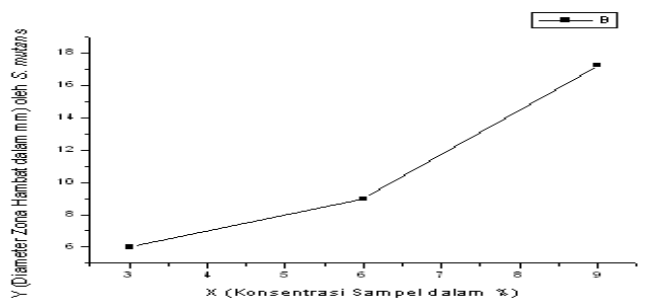

Fig 3. Graph $X$ as concentratio flavonoid total versus $Y$ as inhibitory activity by $S$. Mutans

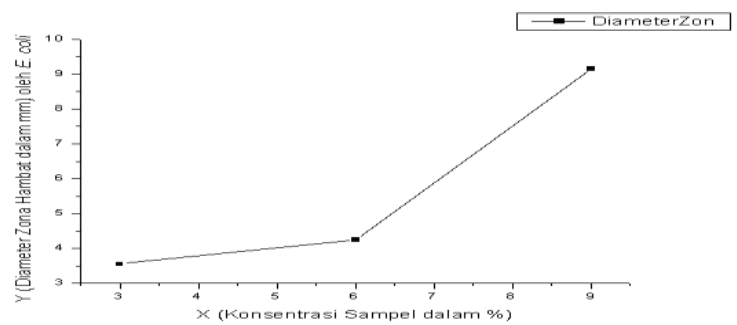

Fig 4. Graph $\mathrm{X}$ as concentration flavonoid total versus $\mathrm{Y}$ as inhibitory activity by $E$. coli

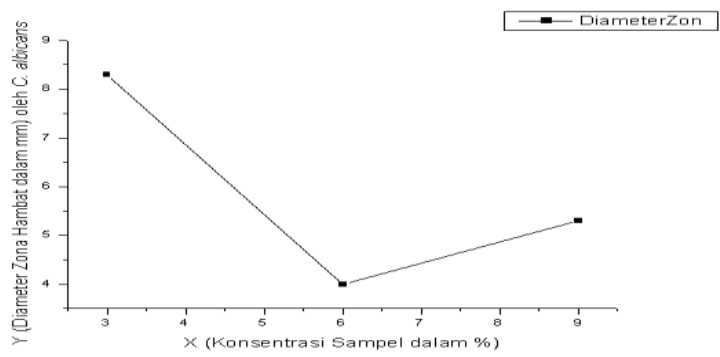

Fig 5. Graph $X$ as concentration flavonoid total versus $Y$ as inhibition activity by Candida albicans

\section{Discussion}

The phytochemical test of fresh mistletoe leaves, Alkaloid test was performed, among others, methanol extract of mistletoe leaves with addition of Meyer, Dragondorf, Wagner and Bouchardat reagents did not give any color change (negative alkaloids) nor did saponin produce constant foam (negative saponin). For Phenolic test of methanol extract with $1 \% \mathrm{FeCl}_{3}$ addition of discoloration of blackish brown (positive phenolic) and with ethyl acetate extract plus $\mathrm{FeCl}_{3} 1 \%$ giving a blackish brown color (positive flavonoids) as well as terpenooid test with $\mathrm{CeSO} 4$ giving red color on TLC plate and with Lieberman Bouchad reactor giving a change in the blackish red color.lt could be seen from Table 1 that the Positive Sign ++++ shows strong and contrasting color changes indicating that mistletoe leaves contain secondary metabolite compounds namely Phenolic, Flavonoid and Terpenoid.

Table 2 Observations with BSLT at $1000 \mathrm{ppm}$ concentrations showed total mortality of shrimp larvae after 24 hours. The reaction tube containing the shrimp larvae with the concentration of $100 \mathrm{ppm}$ extract experienced an average mortality of 1.3 on 10 shrimp larvae and at $10 \mathrm{ppm}$ experienced a mean mortality of 0.6 scale of 10 shrimp larvae in each test tube. From Table 3 observation test, the activity of toxicity with BSLT for 24 hours obtained \% mortality at total flavonoid concentration of mistletoe $10 \mathrm{ppm}$ was $40 \%, 100 \mathrm{ppm}$ was $57 \%$ and $1000 \mathrm{ppm}$ was $100 \%$.

If $\mathrm{LC}_{50}$ (Lethal Concentration 50) is the antilog of death of shrimp larvae in $50 \%$ then obtained $\mathrm{LC}_{50}$ of $30,06 \mathrm{mg} / \mathrm{L}$. According to Meyer et al. (1982), an extract was considered toxic if it has a value of $\mathrm{LC} 50$ $<1000 \mathrm{ppm}$ whereas for pure compounds said toxic if LC50 $<200 \mathrm{ppm}$. LC50 was the concentration of a chemical compound in air or in water that can cause $50 \%$ of death in a population of test animals or certain living things. While the $\mathrm{LD}_{50}$ (Lethal Dossage $50)$ is a dose of a chemical compound which can cause $50 \%$ of the death of the test animal administered to any prescribed individual or, more precisely, a statistically obtained single dose of a substance that can cause $50 \%$ of animal deaths. As sample which was analogyzed of shrimp larvae (Artemia salina) has the same cell division with cancer cell division, after shrimp cysts hatched at 2448 hours, shrimp larvae grew rapidly so that it was assumed as abnormal cell growth.

Table 4, be seen that the inhibition zone of samples with $E$. coli as gram negartif bacteria, $S$. mutans as gram positive bacteria and Candida albicans as fungi. According to Davis et al. (1971), the provision of antibacterial activity strength of an extract was based on an inhibit zone where, if $<5$ $\mathrm{mm}$, the inhibitory power was weak, if 5-10 mm inhibitory power was moderate, $10-20 \mathrm{~mm}$ inhibitiveness was strong and $>20 \mathrm{~mm}$ its inhibitory power was very strong. Table 5 explained that inhibitory power of $S$. mutans, E. coli and Candida albicans increased with concentration of total flavonoid of mistletoe leaves, it proved that the antimicrobial was effective to be developed as an antibacterial agent. Flavonoids played a role in inhibition of DNA-RNA synthesis by intercalation or hydrogen bonding with the accumulation of nucleic acid bases, and the role of inhibiting energy metabolism. These compounds disrupt energy metabolism by inhibiting the respiratory system 
because it required enough energy for the active absorption of various metabolites and for macromolecular biosynthesis (Nuria et al., 2009).

\section{Conclusion}

The results of research conducted on mistletoe leaves of Polyalthia longifolia tree could be concluded as followed:

To test the toxicity activity of mistletoe leaves from Polyalthia longifolia trees using Brine Shrimp Lethality Test (BSLT) obtained $\mathrm{LC}_{50}$ of $30.06 \mathrm{mg} / \mathrm{L}$ which means toxicity activity against shrimp larvae (Artemia salina Leach) was quite toxic. To test the antimicrobial activity of mistletoe leaves from Polyalthia longifolia trees using diffusion method, in order to obtain inhibit zone on $S$. mutans the concentration of extract are $3 \%, 6 \%$ and $9 \%$ respectively are $6 ; 9$ and $17.25 \mathrm{~mm}$, on $E$. coli is 3.55 ; 4.25 and $9.15 \mathrm{~mm}$ and at $C$. albicans is $8.30 ; 4$ and $5.30 \mathrm{~mm}$ where E.coli and $S$. mutans inhibitory power were the greater than $C$. albicans, but once the three microbes were concluded effective to be developed as antimicrobial agents.

\section{Acknowledgments}

Mr. Lamek Marpaung M.Phil, Ph.D who contributed a lot in the author's research.

\section{References}

Davis, W.W., \& Stout, T.R. (1971). Disc Plate Method of Microbiological Antibiotic Assay 1. Factors Influencing Variability and Error. Applied Microbiology. 22, 659-665.

Detroit Digestive Ferments Company. (1985). Difco manual: dehydrated culture media and reagents for microbiology. Difco laboratories.

Fatmawati, D.A. (2008). Pola Protein dan Kandungan Kurkuminoid Rimpang Temulawak (Curcuma Xanthorrhiza Roxb.). FMIPA. ITB. Bandung.

Harborne, J.B. (1987). Metode Fitokimia: Penuntun Cara Modern Menganalisis Tumbuhan Edisi Kedua. Bandung: ITB.

Lakshmi, A.P.A.R.N.A., Rao, Y., Bhargavi, C., \& Seelam, U. (2011). Antidiabetic and Wound Healing Activity of Various Bark Extracts of Polyalthialongifolia. Asian Journal of Pharmaceutical and Clinical Research. 4, 109-113.

Madigan, M.T., Martinko, J. M., \& Parker, ]. (2017). Brock biology of microorganisms. (vol. 13) Pearson.

Malairajan, P., Gopalakrishnan, G., Narasimhan, S., \& Veni, K.J.K. (2008). Evalution of anti-ulcer activity of Polyalthia longifolia (Sonn.) Thwaites in experimental animals. Indian J Pharmacol. 40, 126-128.

Manjula, S.N., Kenganora, M., Parihar, V.K., Kumar, S., Nayak, P.G., Kumar, N., \& Rao, C.M. (2010). Antitumor and antioxidant activity of Polyalthia longifolia stem bark ethanol extract. Pharmaceutical biology. 48, 690-696.

Mclaughlin, J.L., Rogers, L.L., \& Anderson, J.E. (1998). The use of biological assays to evaluate botanicals. Drug information journal. 32, 513-524.

Meyer, B.N., Ferrigni, N.R., Putnam, J.E., Jacobsen, L.B., Nichols, D.J., \& McLaughlin, J.L. (1982). Brine shrimp: a convenient general bioassay for active plant constituents. Planta medica. 45, 31-34.

Nuria, M.C., \& Faizatun, A. (2009). Uji Aktivitas Antibakteri Ekstrak Etanol Daun larak Pagar (Jatropha Curcas L) Terhadap Bakteri Staphylococcus aureus ATCC 25923, Escherichia coli ATCC 25922, dan Salmonella typhi ATCC 1408. MEDIAGRO. 5, 26-37.

Pitojo, S. (1996). Benalu hortikultura: Pengendalian dan pemanfaatan. Trubus Agriwidya, Ungaran.

Purnomo, B. (2000). Uji Ketoksikan Akut Fraksi Etanol Daun Benalu (Dendropthae Sp) Pada Mencit Jantan Dan Uji Kandungan Kimia. Fakultas Farmasi Universitas Gadjah Mada. Yogyakarta.

Rastogi, R.P., \& Mehrotra, B.N. (1995). Compendium of Indian medicinal plants. New Delhi: CDRI.

RI, D.J.P. (2000). Parameter Standarisasi Umum Ekstrak Tumbuhan Obat. Departemen Kesehatan Republik Indonesia, Jakarta. 1, 10-11.

Sari, F.P., \& Sari, S.M. (2011). Ekstraksi Zat Aktif Antimikroba dari Tanaman Yodium (Jatropha multifida Linn) sebgai Bahan Baku Alternatif Antibiotik Alami. Semarang: Fakultas Teknik Universitas Diponegoro. 